\title{
KEFAHAMAN NILAI ETIKA DAN MORAL PELAJAR DI INSTITUSI PENGAJIAN TINGGI: SATU SOROTAN LITERATUR
}

(Understanding of The Dimensions of Ethical and Moral Values In Higher Learning Institutions: A Literature Review)

\author{
RUSLAN HASSAN*, FARID MAT ZAIN, KASEH ABU BAKAR \& AZMUL FAHIMI \\ KAMARUZZAMAN
}

\begin{abstract}
ABSTRAK
Perkara yang harus ditekankan bagi melahirkan pelajar yang berakhlak mulia adalah dengan memberi penekanan kepada aspek kefahaman yang jelas berkaitan nilai etika dan moral yang menjurus kepada pembinaan peradaban. Ini bagi melahirkan pelajar yang berilmu dan beriman, berakhlak mulia serta bersedia menangani cabaran semasa dunia global. Kajian ini bertujuan mengenal pasti kefahaman pelajar terhadap dimensi nilai etika dan moral dari sudut keperluan dan mengenal pasti pelaksanaan kaedah penerapan nilai etika dan moral terhadap pelajar. Kajian ini merupakan kajian literatur melalui analisis kandungan dan dihuraikan secara deskriptif. Pengumpulan data diperoleh daripada penulisan ilmiah seperti tesis, disertasi, buku, jurnal, kertas kerja, seminar prosiding dan laman sesawang yang berautoriti. Hasil kajian menunjukkan nilai etika dan moral semakin tidak dititikberatkan dan memperlihatkan senario semakin terpinggir dalam kehidupan seharian khususnya dalam kalangan pelajar. Implikasi kajian ini boleh digunakan sebagai garis panduan kepada organisasi yang terlibat dalam usaha mereka untuk membangunkan nilai etika dan moral ini dalam memperkukuhkan sahsiah mahasiswa ketika di alam universiti sebelum mereka melibatkan diri ke alam pekerjaan kelak.
\end{abstract}

Kata kunci: Kefahaman; Nilai; Etika; Moral

\begin{abstract}
The issue that needed to be focused in producing students with good morals is to emphasise the aspect of clear understanding regarding ethical and moral values leading to the construction of civilization. This is to produce students who are knowledgeable and faithful, virtuous and ready to deal with the current challenges of the global world. This study aims to identify students' understanding of the dimensions of ethical and moral values in terms of needs and to identify the implementation methods in applying ethical and moral values to students. This study is based from literature review through content analysis. The data collection is obtained from scholarly sources such as theses, dissertations, books, journals, papers, seminar proceedings and authoritative websites. The results in the study show that ethical and moral values among the students are increasingly not being emphasised and these values are increasingly being marginalized in their daily life. The implications from this study can be used as a guidelines to students in the university before they opted to the working environment later.
\end{abstract}

Keywords: Understanding; Values; Ethics; Attitude; Morals 


\section{PENGENALAN}

Pembentukan sesebuah negara yang maju adalah merujuk kepada keupayaan sesebuah negara tersebut membangunkan pemikiran dan nilai rakyat dengan sempurna. Hal ini ditegaskan oleh Mohd Ridhuan (2007) yang mengutarakan bahawa kriteria sebuah negara yang ingin mencapai status negara membangun dan maju adalah dengan mempunyai sistem pendidikan yang mantap dan berkesan tidak hanya menitikberatkan kemajuan dari segi pembangunan material tetapi turut membangunkan pembangunan nilai yang meliputi soal tingkah laku manusia. Persoalannya, sejauhmanakah kefahaman para pelajar terhadap pentingnya nilai etika dan moral dalam diri mereka untuk membentuk sebuah negara yang mempunyai peradaban yang tinggi di mata dunia? Apatah lagi sejak akhir ini penularan gejala sosial dan keruntuhan nilai etika dan akhlak yang melibatkan para pelajar universiti awam dan swasta turut memberi kesan yang negatif kepada masyarakat. Menurut Abdul Muqsith et. al (2017), amalan yang tidak beretika dan berakhlak telah menjadi satu isu yang kritikal dalam kalangan pelajar kemahiran kejuruteraan. Dapatan kajian ini memperlihatkan antara kes-kes yang dilakukan pelajar seperti menipu di dalam peperiksaan, melayari media sosial ketika sesi kuliah, datang lewat ke kelas dan sebagainya. Ini telah dibuktikan melalui kajian-kajian yang lepas (Al-Hassan, Faridahwati dan Kamil 2013; Shukri and Musa Yusof 2012) yang masih tidak ada jalan penyelesaian apabila gejala sosial dalam kalangan pelajar semakin membimbangkan.

Tindakan seorang graduan universiti tempatan menjerit dan menunjukkan tanda protes sejurus selepas menerima skrol ijazah sarjana muda dalam majlis istiadat konvokesyen mengundang pelbagai reaksi daripada masyarakat (Sinar Harian 15 Oktober 2019; The Star Online 15 Oktober 2019) dan jelas membuktikan nilai etika dan moral yang semakin pincang di kalangan generasi muda. Senario ini menggambarkan bahawa nilai etika dan moral seorang yang bergelar mahasiswa semakin merudum dan ini menunjukkan bahawa tiada nilai peradaban yang tinggi yang sepatutnya dicerminkan oleh mahasiswa yang berilmu. Situasi ini adalah sangat membimbangkan memandangkan sekiranya mahasiswa yang berilmu, di kalangan penuntut pengajian tinggi juga telah menunjukkan nilai etika dan moral yang rendah, apatah lagi golongan generasi muda yang tidak berpeluang menimba ilmu di peringkat tinggi, sedangkan para mahasiswa ini perlu ditanam, diasuh, dan dibentuk dalam diri seseorang pelajar dengan nilai etika dan moral kerana mereka adalah nadi kepada pembangunan negara pada masa hadapan. Justeru, kajian literatur ini akan membincangkan dimensi dan kefahaman nilai etika dan moral pelajar yang perlu diterapkan di dalam diri pelajar sebagai benteng utama dalam pemantapan sahsiah mereka.

\section{Konsep Nilai}

Menurut Shukri (2002) Nilai ialah konsep, dalaman ataupun luaran yang bertujuan untuk membezakan seseorang individu, perwatakan, ciri-ciri sesuatu kumpulan, ataupun keinginan yang mempengaruhi pemilihan sesuatu cara hidup mereka, matlamat dan tujuan sesuatu perlakuan itu. Nilai juga dikata sebagai apa sahaja yang dirasai oleh manusia, kehendak atau hasrat yang ditetapkan oleh pandangan akal dan disimpulkan baik dalam kehidupan manusia. Misalnya nilai-nilai baik adalah benar, amanah, dan jujur manakala nilai buruk seperti berdusta, menipu dan dengki. Manakala Amini Amir (2007) memberi takrifan nilai ialah sesuatu yang mempunyai harga, kepentingan atau keburukan. Nilai kebiasaannya diletakkan ukuran sama ada positif, negatif ataupun neutral. Makna nilai juga ialah pengukuran sesuatu yang dihajati dan dihargai. Kebiasaannya mencakupi aspek taraf, darjat, kualiti dan mutu. Nilai Islam misalnya berasaskan kepada prinsip ajaran kebaikan Islam yang mengandungi nilai-nilai murni, positif dan akhlak. 
Menurut Sufean (1995) di dalam bukunya bertajuk Pengajaran Nilai Dalam Kurikulum menyatakan sikap dan nilai saling berkait dan melengkapi di antara satu sama lain tetapi keduaduanya tidak serupa. Sufean (1995) juga menambah nilai adalah terbitan dan sikap adalah gagasan seperti jika seseorang menyanjungi nilai kemewahan, maka individu berkenaan bersikap positif terhadap produktiviti dan keuntungan, dan bersikap negatif terhadap kemalasan dan kerugian. Ini bermakna nilai adalah lebih abstrak daripada sikap. Oleh yang demikian, nilai dan sikap mendorong dan mempengaruhi tingkahlaku dan pemikiran, tetapi yang menjadi pengimbangtara ialah nilai bukannya sikap. Dalam pengertian yang lain menurut Institut Tadbir Awam Negara (INTAN) (1993), menyatakan nilai ditakrifkan sebagai kepercayaan yang mendorong seseorang atau sesebuah institusi untuk bertindak mengikut pemilihan yang berasaskan nilai-nilai utama masyarakat. Seterusnya Latifah (2012), menyatakan nilai murni dapat didefinisikan sebagai perlakuan yang baik, peradaban dan tatasusila individu manusia dalam hubungannya sesama manusia, alam dan Tuhan.

Nilai-nilai murni dalam mewujudkan perpaduan kaum telah dibincangkan oleh Hasnah Hussin (2009) dalam bukunya bertajuk Artikel kenegaraan dan hubungan etnik. Penulis telah mendedahkan beberapa nilai murni yang perlu rakyat Malaysia amalkan bagi menjayakan lagi agenda perpaduan kaum. Antaranya ialah kerjasama, tolak ansur, taat setia, ikhlas, berprasangka baik, tolong-menolong, bersimpati, berfikiran terbuka, bersatu, dan memahami persamaan dan perbezaan. Berbagai-bagai nilai murni telah didedahkan untuk tatapan semua kaum dan etnik di negara ini sebagai amalan mereka seharian. Pengamalan nilai-nilai murni adalah perlu bagi memastikan usaha pemerintah untuk perpaduan kaum di negara ini tercapai. Semua pihak memainkan peranan dan apa yang lebih penting adalah keinginan kita untuk melakukannya dan melaksanakannya. Dalam pada itu, Sapie et al. (2016) juga berpendapat penerapan nilai-nilai murni adalah suatu yang mesti dilakukan oleh guru sepertimana yang telah digariskan dalam Falsafah Pendidikan Kebangsaan (FPK) dan Standard Guru Malaysia. Justeru, beliau mencadangkan agar penerapan nilai-nilai murni ini perlu disemai bagi meningkatkan akhlak yang mulia kepada golongan pelajar. Ini kerana, golongan pelajar merupakan tenaga simpanan negara yang bakal menjadi pemimpin masa hadapan, penyumbang budaya, penggerak kemajuan dan pelopor pembangunan bagi sesebuah masyarakat.

Di samping itu, nilai merupakan dimensi yang amat relevan dengan sikap dan amalan masyarakat dan ini menjadikannya amat penting dalam proses pembangunan. Mahadi and Sino (2007) dalam kajian mereka mendapati perlunya nilai peningkatan diri wujud dalam komuniti seperti di negara maju untuk membolehkan setiap negara membangun secara berkesan di samping nilai kesediaan untuk berubah. Menurut Mohd Ismail et al. (2004), pembentukan nilai dan kecemerlangan bagi melahirkan generasi muda yang mapan dalam menghadapi era pasca modenisme, aspek kerohanian, pengurusan diri, bersosial, berorganisasi, kepimpinan, berkomunikasi dan berdakwah perlu dikuasai bagi memastikan generasi muda mempunyai persediaan sebagai seorang pemuda yang berwawasan. Dalam pada itu, Zaid Ahmad et al. (2013) juga berpendapat cabaran dalam menerapkan budaya dan sistem nilai yang dapat dihayati dalam kehidupan masyarakat juga bukanlah sesuatu yang mudah. Hal ini kerana, masyarakat yang amat pelbagai sifatnya secara semula jadinya memiliki pelbagai kelainan dan perbezaan sama ada dari segi cara hidup mahupun penghayatan amalan dan sistem nilai. Justeru, nilai-nilai teras yang perlu dijadikan asas kepada integriti masyarakat hari ini amat tepat (Khairul 'Azmi dan Nooraini 2009) apabila dikaji serta memahaminya melalui sifat-sifat Nabi Muhammad SAW iaitu siddiq (benar), amanah (dipercayai), tabligh (menyampaikan) dan fatonah (bijaksana) adalah patut diamalkan oleh pelajar. Ini bermakna, sekiranya pelajar menjadikan nilai teras ini sebagai budaya dan amalan dalam kehidupan, adalah diyakini tahap integriti masyarakat akan berada di tahap yang tinggi. 


\section{Konsep Etika}

Menurut Mustafa (2002) dalam bukunya bertajuk Tamadun Islam menjelaskan definisi etika yang berasal daripada bahasa Inggeris 'ethic'. Kata ini berasal dari kata Greek 'ethos' yang membawa maksud nilai-nilai, atau perkara yang berkaitan dengan sikap yang menentukan tingkah laku sesuatu golongan. Ia terbahagi kepada dua:

i. Normati, iaitu panduan dan peraturan berkaitan dengan tingkah laku yang baik dan jahat.

ii. Mataethic, yang terbahagi kepada dua, iaitu 'analitik' yang berfungsi menganalisis semua, peraturan yang berkaitan dengan tingkah laku baik dan jahat, dan 'kritikal' yang berfungsi untuk mengkritik terhadap apa-apa yang telah dianalisis. Tujuannya ialah untuk memperkukuhkan lagi etika.

Terdapat beberapa pandangan berkenaan definisi yang tepat mengenai etika di mana Zaharah, Abu Daud dan Nazri (2009) memberi penegasan bahawa etika merupakan keupayaan seseorang manusia dalam membezakan perkara betul dan salah berdasarkan pertimbangan pemikiran dan akhirnya melakukan perkara yang betul. Namun begitu penakrifan yang berbeza dinyatakan oleh Roziah, Zulkarnain dan Nasrudin (2011) yang menghujahkan bahawa etika adalah suatu sistem tingkah laku manusia yang bersumberkan kepada daya pemikiran manusia itu sendiri. Berdasarkan Hamzah (1985) pula, etika bermaksud satu ilmu dalam menyelidik pelakuan baik dan buruk dengan memerhatikan tingkah laku manusia menggunakan akal fikiran. Kajian Abdul Muqsith et. al (2017) telah menjelaskan konsep etika yang perlu difahami secara mendalam di mana terdapat tiga dimensi asas yang mendokong konsep etika yang terdiri daripada aspek kognitif, afektif dan psikomotor. Menurut Sharifah Hayati (2010) etika merupakan himpunan nilai dan moral yang menjadi piawai dalam membentuk tingkah laku individu, organisasi dan kerjaya.

Pelbagai definisi telah diberikan berkaitan etika. Konsep etika ini boleh disimpulkan sebagai suatu set peraturan kehidupan manusia yang menjadi asas dan panduan dalam menjalani kehidupan berprinsip dan mengikut peraturan yang betul. Etika menjadi pengukur kepada penentuan diri manusia dalam konteks interaksi manusia dengan alam, interaksi sesama manusia dan interaksi dengan Pencipta. Etika dalam kehidupan manusia sejagat memainkan peranan penting dalam pelbagai bidang antaranya pengurusan, perancangan, pembangunan, agama dan ekonomi. Etika yang baik wajar dijadikan teras dalam kehidupan insan bagi mencapai kesejahteraan dan keharmonian hidup. Oleh itu, konsep etika ini turut diterima pakai dalam sektor pekerjaan awam dan swasta dan menjadi garis panduan dalam sesebuah organisasi seperti Etika Perkhidmatan Awam, Kod Etika Kejuruteraan, Plan Integriti dan Kod Etika JAKIM, Etika Kerja Islam dan sebagainya.

Kajian yang melibatkan etika kerja Islam juga mendapat perhatian pengkaji lepas. Siti Arni et al. (2016) dalam kajian mereka telah menyenaraikan lima sifat-sifat etika kerja Islam sebagai panduan iaitu melakukan pekerjaan untuk mendapat keredhaan Allah SWT, amanah, ganjaran, keadilan dan hubungan majikan dan pekerja yang harmoni. Kajian seumpama ini juga turut dilakukan Zainal Yang (2003); Zaharah (2009); Megat Ayop (2016) mengenai nilai, etika dan budaya kerja dalam pentadbiran sektor awam di Malaysia. Beliau telah menekankan nilai, etika dan budaya kerja dari perspektif Islam perlu diberi perhatian seperti a) setiap tindakan harus diiringi dengan niat, b) ketelitian dan berpengetahuan dalam semua usaha (itqan), c) kecekapan dan kekesanan (ihsan), d) keikhlasan, e) kehendak kepada kecemerlangan, f) penilaian diri yang berterusan, dan g) fikiran sentiasa mengingati kepada Yang Maha Kuasa. Sealiran dengan itu, kajian Enida et al. (2019) berkaitan etika kerja Islam sebagai pembolehubah penyederhanaan terhadap niat untuk melakukan rasuah di kalangan penjawat awam turut berpendapat bahawa 8 etika kerja Islam dikenalpasti sebagai pembolehubah penyederhanaan terhadap hubungan faktor dalaman dan niat untuk melakukan 
rasuah iaitu 1) nilai taqwa, 2) nilai ihsan, 3) amal soleh, 4) nilai al-Birr, 5) nilai al-Qist, 6) nilai masuliyah, 7) nilai ma'aruf, dan 8) nilai itqan. Secara ringkasnya dapat disimpulkan bahawa prinsip etika nilai kerja Islam yang dibincangkan mampu membentuk nilai kerohanian dalam diri penjawat awam.

Kajian lepas juga mendapati etika dan nilai yang lahir daripada diri seseorang menjadi ukuran baik atau buruknya seseorang individu. Lantas, pembinaan sahsiah dan personaliti merupakan antara aspek penting yang perlu ditekankan oleh setiap individu bagi menyerlahkan nilai kognitif, afektif, dan tingkah lakunya sewaktu berinteraksi dengan persekitaran dan masyarakat di sekelilingnya (Muhammad Iqbal 2018). Ini bertepatan dengan dapatan kajian Abdul Muqsith et al. (2017) mendapati masalah etika dan akhlak yang berlaku adalah tinggi dan signifikan berdasarkan kepada peratusan yang diperoleh iaitu $72.9 \%$ pelajar mengaku terlibat sekurang-kurangnya sekali dalam kelakuan tidak beretika dan tidak berakhlak sepanjang pengajian mereka. Kebimbangan yang timbul adalah masalah etika dan akhlak ini terus berlaku sehingga terbawa-bawa ke alam pekerjaan. Dalam beberapa kajian mendapati hubungan yang kuat diantara kelakuan yang kurang baik ketika belajar dengan tingkahlaku yang tidak beretika ketika kerja (Nonis dan Swifh 2001; Crown dan Spiller 1998; Lawson 2004). Hal ini jelas menunjukkan bahawa kecenderungan untuk menipu di tempat kerja berkait rapat dengan amalan yang tidak beretika dan berakhlak ketika di pusat pengajian.

\section{Konsep Moral}

Moral diertikan sebagai ajaran atau pegangan berkaitan buruk baik sesuatu perbuatan, sikap atau kelakuan yang diukur dari segi baik dan buruk sesuatu akhlak. Menurut Manshuruddin (2003) moral dalam konteks Islam membawa maksud akhlak, budi pekerti atau watak. Istilah moral pula berasal daripada bahasa Latin mores bermaksud keadaan satu-satu tindakan manusia, sama ada secara individu atau kelompok (Ghazali, 2007). Selain itu, mores juga beerti kebiasaan atau adat (Bertens 2003). Istilah mores ini dapat diertikan juga sebagai ethos dalam bahasa Greek (Runes 1979). Menurut definisi beberapa kamus (Noresah (ed), 2005; Poerwadarminto 2006; Thompson (ed) 1995), moral bermaksud ajaran atau pegangan tentang baik buruk sesuatu perkataan, kelakuan, sikap atau cara yang diukur dari segi baik buruk sesuatu akhlak.

Pengertian moral meliputi perbuatan, tingkah laku atau ucapan seseorang semasa berinteraksi dengan manusia lain. Dalam moral diatur segala perbuatan yang dinilai baik dan perlu dilakukan, dan perbuatan yang dinilai tidak baik perlu dihindari. Menurut Bertens (2003) apabila moral dikaitkan dengan adat ini bermakna sesuatu perkara yang dilakukan oleh seseorang sudah menjadi adat kebiasaan dan diterima oleh masyarakat. Sesuatu perkara yang dilakukan oleh seeorang jika sesuai dengan nilai, diterima dan menyenangkan lingkungan masyarakatnya, maka orang itu dianggap mempunyai moral yang baik dan sebaliknya.

Menurut Zaharah et. al (2015) dalam kajian bertajuk pembangunan akhlak dan moral ke arah masyarakat lestari mendapati pembangunan akhlak dan moral adalah wajib ditekankan kerana ia adalah satu elemen dalam membentuk modal insan ke dalam diri setiap insan. Manakala Bertens (2003) dalam bukunya Etika dan moral untuk pengajian tinggi turut menjelaskan kepentingan etika dan moral dalam kalangan pelajar untuk diamalkan. Pelbagai cabang etika dan moral yang disarankan terhadap pelajar untuk dipraktikkan dalam kehidupan. Bertens juga menekankan tiga pendekatan iaitu etika deskriptif, etika normatif dan metaetika. Etika adalah ilmu yang membincangkan kemoralan atau tentang manusia yang berkait dengan kemoralan. Suatu cara lain untuk merumuskan hal yang sama adalah bahawa etika merupakan ilmu yang menyelidiki tingkah laku moral. 


\section{Keperluan Nilai Etika Dan Moral Terhadap Pelajar}

Kemuliaan sesuatu umat bukan hanya bergantung kepada ilmu yang tinggi tetapi juga kemurnian akhlak yang dimiliki. Manusia tidak akan sempurna tanpa mempunyai nilai akhlak yang tinggi. Untuk menentukan nilai-nilai akhlak yang harus dipunyai oleh seorang muslim, Islam menjadikan Al-Quran dan Hadis sebagai sumber rujukan utama. Kehidupan yang berlandaskan peribadi mulia dan bermoral tinggi merupakan aspek yang penting dalam kehidupan bertamadun. Manifestasi kewujudan tamadun terdahulu adalah kehidupan beragama yang membentuk nilai kehidupan yang terpuji dan tinggi moral dan akhlaknya. Ini membawa maksud bahawa agama telah dijadikan panduan utama dalam pembinaan tamadun. (Mohd Nazmi et al. 2011).Sejarah peradaban manusia memperlihatkan proses perubahan sosial dan kebudayaan yang menempuhi waktu yang panjang. Perubahan terjadi dalam kehidupan yang semakin kompleks, bergantung pada bagaimana manusia menyesuaikan diri dengan tahap kemajuan kebudayaannya, termasuk pengaruh ilmu pengetahuan dan penerimaan terhadap perkembangan sains dan teknologi. Peradaban lahir apabila sesebuah masyarakat dan bangsa mencipta dan mengamalkan kehidupan budaya tinggi, khususnya apabila tradisi ilmu meluas dan berpengaruh. (Aziz Deraman 2015).

Dalam konteks ajaran Islam pembangunan etika dan integriti menjurus kepada konsep akhlak seperti pendapat Imam al-Ghazali. Untuk membangunkan integriti dalam kehidupan manusia ia berkaitan dengan keperibadian yang akan melahirkan tingkah laku manusia terhadap Tuhan dan manusia serta makhluk-makhluk yang lain. Menurut (Rashdi et. al 2014) dalam kajiannya merumuskan bahawa etika penting yang perlu dimiliki oleh seseorang pelajar adalah kejujuran dan kebenaran, amanah, keadilan, menepati janji, ihsan, istiqamah, taufian, berilmu dan berkemahiran serta keazaman. Beberapa permasalahan juga turut dibangkitkan oleh pengkaji terutama yang berkaitan pembangunan etika dan moral dalam kursus yang ditawarkan di universiti. Menurut Shahrulanuar et al. (2011), tiga halangan pembangunan etika dan moral dalam kursus yang ditawarkan yang didepani oleh pensyarah adalah 1) pelajar kurang rujukan/bahan/dokumen berkaitan etika dan moral $(68.8 \%), 2)$ tiada garis panduan yang jelas untuk menilai aspek etika dan moral pelajar (68.8\%), 3) kurang prasarana untuk menggalakkan pembangunan etika dan moral pelajar (56.3\%). Ini dapat dilihat seperti jadual di bawah:

Jadual 1.1. Tiga halangan pensyarah dalam pembangunan etika dan moral

\begin{tabular}{clc}
\hline Bil & \multicolumn{1}{c}{ Item } & peratus \\
\hline $\mathbf{1}$ & $\begin{array}{l}\text { Pelajar kurang rujukan/bahan/dokumen berkaitan etika dan } \\
\text { moral }\end{array}$ & $68.8 \%$ \\
\hline $\mathbf{2}$ & $\begin{array}{l}\text { Tiada garis panduan yang jelas untuk menilai aspek etika dan } \\
\text { moral pelajar }\end{array}$ & $68.8 \%$ \\
\hline $\mathbf{3}$ & $\begin{array}{l}\text { Kurang prasarana untuk menggalakkan pembangunan etika } \\
\text { dan moral pelajar }\end{array}$ & $56.3 \%$ \\
\hline
\end{tabular}

Sumber: Shahrulanuar et al. (2011)

Tiga halangan yang dihadapi oleh pelajar adalah 1) tiada garis panduan yang jelas untuk menilai aspek etika dan moral pelajar $(56.4 \%), 2)$ kursus yang diambil banyak menekankan pengetahuan teknikal berbanding aspek etika (52.6\%), 3) kurang prasarana untuk menggalakkan pembangunan etika dan moral pelajar (52.1\%). Kajian ini menunjukkan pentingnya kekuatan yang ada pada elemen-elemen etika dan moral dalam memperbaiki peribadi pelajar. 
Jadual 1.2. Tiga halangan pelajar dalam pembangunan etika dan moral

\begin{tabular}{clcc}
\hline Bil & \multicolumn{1}{c}{ Item } & peratus \\
\hline $\mathbf{1}$ & $\begin{array}{l}\text { Tiada garis panduan yang jelas untuk menilai aspek etika dan } \\
\text { moral pelajar }\end{array}$ & $56.4 \%$ \\
\hline $\mathbf{2}$ & $\begin{array}{l}\text { Kursus yang diambil banyak menekankan pengetahuan } \\
\text { teknikal berbanding aspek etika }\end{array}$ & $52.6 \%$ \\
\hline $\mathbf{3}$ & $\begin{array}{l}\text { Kurang prasarana untuk menggalakkan pembangunan etika } \\
\text { dan moral pelajar }\end{array}$ & $52.1 \%$ \\
\hline
\end{tabular}

Sumber: Shahrulanuar et al. (2011)

Salah satu cabaran negara untuk menjadi sebuah negara yang maju adalah untuk melahirkan masyarakat yang bermoral dan beretika. Sejarah telah membuktikan betapa corak hidup bermasyarakat pada zaman dahulu dicerminkan melalui nilai-nilai yang menjadi asas perkembangan ketamadunan. Nilai pada asasnya merupakan tanggapan yang mempengaruhi corak pilihan terhadap bentuk, alat dan matlamat tindakan. Nilai menjadi ukuran dan pegangan tentang baik buruk atau cantik hodoh sesuatu perlakuan berasaskan kelaziman atau kebiasaan masyarakat. Sebagai seorang pelajar yang mendapat didikan di peringkat tinggi dipupuk dengan nilai-nilai sosial yang dikongsi bersama dengan orang lain dan nilai itu akhirnya menjadi kelaziman dalam masyarakat. Daripada kelaziman inilah maka ianya menjadi nilai peradaban yang bersifat mutlak dimiliki oleh sesebuah ketamadunan. (Taufik et al. 2018)

\section{Penerapan Nilai Etika Dan Moral Dalam Pengajaran Dan Pembelajaran (PdP)}

Jika diselusuri kepada sistem pendidikan di Malaysia, pihak Kementerian Pendidikan Malaysia amat menitik beratkan pembangunan sahsiah ke dalam diri pelajar. Hal yang demikian adalah selari dengan Laporan Pelan Pembangunan Pendidikan 2013-2025 yang menegaskan bahawa:

\footnotetext{
"Sistem pendidikan akan mempersiapkan setiap murid supaya berani menghadapi cabaran masa depan, menyelesaikan konflik secara aman, membuat keputusan yang wajar dalam situasi kritikal, dan mempunyai keberanian melakukan apa yang betul. Penekanan diberikan kepada setiap murid dengan mewujudkan satu set prinsip, termasuk nilai bersama yang kukuh yang didukung oleh semua rakyat Malaysia dan merangkumi kerohanian, intergriti dan tanggungjawab sivik."
}

Kajian mengenai 17 dimensi nilai murni dalam kalangan pelajar sekolah menengah di Malaysia juga telah dilakukan. Mohamad Khairi, Asmawati and Samsilah (2015) mendapati secara keseluruhannya penghayatan nilai murni pelajar berada pada tahap sederhana tinggi. Kajian juga mendapati hanya tiga dimensi nilai murni yang menunjukkan tahap penghayatan yang tinggi iaitu nilai kesyukuran, nilai patriotisme dan nilai hormat menghormati. Manakala 14 dimensi nilai murni menunjukkan tahap penghayatan yang sederhana tinggi. Nilai murni yang terendah dalam penghayatan pelajar ialah nilai berdikari, nilai semangat bermasyarakat dan nilai kerajinan. Berbeza pula kajian yang dilakukan Latifah et al. (2012) membincangkan tentang penerapan nilai murni dan pembentukan jati diri kanak-kanak pra sekolah melalui penggunaan bahan-bahan multimedia. Dapatan menunjukkan bahawa responden memahami pelajaran yang dipelajari dengan menunjukkan minat yang tinggi serta nilai berani tampil ke hadapan untuk menyelesaikan masalah dalam pembelajaran dapat dihasilkan. Perisian bahanbahan multimedia sememangnya berfungsi sebagai alat pendidikan yang berpotensi untuk menggalakkan semangat belajar dan sebagai ejen bagi menerapkan unsur nilai-nilai murni dalam membentuk akhlak, peribadi dan sahsiah kanak-kanak sejak diperingkat awal lagi. 
Manakala dengan kajian Mohamad Khairi et al. (2019) yang mengkhususkan kepada keperluan penggunaan modul etika kerja guru dalam meningkatkan penghayatan nilai pelajar. Pembinaan modul tersebut telah dibuat berdasarkan model pembinaan modul yang telah diperkenalkan oleh Sidek Noah. Model etika kerja yang dihasilkan melalui 9 fasa telah di nilai oleh pakar penilai modul. Hasil yang diperolehi mendapati bahawa aras pekali secara keseluruhan bagi kesahan modul adalah 0.79 dan kebolehpercayaan Alpha Cronbach untuk model etika kerja KPM adalah tinggi iaitu 0.95. Kajian mendapati, semua aktiviti yang terkandung dalam modul adalah sesuai dan boleh digunakan sebagai alat, bahan, sumber dan panduan yang boleh memberi bimbingan, kesedaran, keinsafan, semangat dan motivasi kepada semua guru sekolah di seluruh Malaysia. Ini menunjukkan bahawa modul ini berupaya meningkatkan kesedaran dan kualiti tingkah laku para guru dan pelajar sekaligus meningkatkan penghayatan nilai murni dalam kalangan guru dan pelajar.

Perkara yang harus ditekankan bagi melahirkan pelajar yang berakhlak mulia adalah pelaksanaaan penerapan nilai sama ada secara langsung atau tidak langsung. Norazri (2015) dalam tesis sarjana berkaitan Penerapan Nilai-Nilai Murni Dalam Proses Pengajaran dan Pembelajaran Ke Arah Pembentukan Sahsiah Pelajar di Kolej Kemahiran Tinggi Mara. Kajian dijalankan untuk mengenal pasti tahap penerapan nilai-nilai murni dalam kalangan pensyarah sewaktu proses pengajaran dan pembelajaran. Responden kajian terdiri daripada 100 orang pensyarah dan 300 orang pelajar. Instrumen yang digunakan adalah berbentuk borang soal selidik ke atas pensyarah dan pelajar dari aspek kerjasama, hormat menghormati dan bertanggungjawab. Hasil ujian t menunjukkan bahawa penerapan nilai-nilai murni dalam kalangan pensyarah berada pada tahap tinggi dan terdapat perbezaan yang signifikan dari perspektif pensyarah dan pelajar dalam penerapan nilai-nilai murni.

Elemen nilai berasaskan hubungan turut dibincangkan dalam artikel jurnal yang ditulis Saedah Siraj et al. (2016). Kajian yang dijalankan merupakan satu kajian kuantitatif dengan kaedah tinjauan mengunakan soal selidik. Seramai 65 orang pelajar kejuruteraan daripada Politeknik Malaysia sebagai responden kajian. Kesemua pelajar ini adalah mengikuti metod pengajian yang pendekatan Work-Based Learning (WBL). Hasil dapatan kajian menunjukkan bahawa kesemua elemen hubungan adalah berada pada tahap yang diperlukan di mana hubungan pelajar dengan rakan berada pada kedudukan pertama berdasarkan penafsiran skor min. Manakala hubungan dengan alam pada kedudukan kedua, hubungan pelajar dengan mentor adalah di kedudukan ketiga, hubungan dengan Allah SWT/Tuhan pada kedudukan keempat dan hubungan dengan diri pada kedudukan kelima. Ini membuktikan bahawa proses penerapan nilai dalam pengajian kejuruteraan yang berasaskan Work-Based Learning (WBL) perlu ditinjau dan diperkasakan agar dapat melahirkan pelajar teknikal dan vokasional yang seimbang.

Kajian berkaitan kemahiran generik hubungan nilai amanah dengan etika dan moral profesional dalam kalangan pelajar universiti teknikal Malaysia telah dilakukan. Kaedah yang digunakan adalah kajian kuantitatif dengan tujuan untuk mengkaji hubungan akhlak Islam (amanah) dengan etika dan moral profesional berasaskan kerangka teori kepada Model Kementerian Pengajian Tinggi 2006 yang menggariskan tujuh kemahiran asas yang perlu dikuasai dan kemahiran insaniah tambahan. Rashidi et al. (2014) mendapati nilai min keseluruhan penguasaan pelajar terhadap kemahiran etika dan moral profesional yang berada pada tahap tinggi $(\mathrm{M}=4.40)$. Namun, hasil keputusan analisis bagi Korelasi Pearson yang mengukur hubungan di antara etika dan moral profesional dengan nilai amanah dapat dilihat bahawa nilai pekali $(\mathrm{r}=.627, \mathrm{p}<.05)$ jelas menunjukkan hubungan yang sederhana kuat yang signifikan antara penguasaan etika dan moral profesional dengan nilai amanah. Ini menunjukkan bahawa kemahiran tentang etika dan moral profesional boleh dilatih atau diajar melalui kaedah secara formal atau secara informal dan ianya salah satu kaedah yang berkesan bagi memberi pendedahan kepada pelajar atau pekerja mengenai kepentingan etika dan moral 
serta isu-isu berkenaan etika dan moral. Pengkaji juga telah mencadangkan supaya modulmodul kursus harus dikaji semula, diperhalusi dan dirombak sekiranya perlu bagi melengkapkan set nilai yang berkualiti kepada individu.

Di peringkat universiti pula, kerelevanan antara bahan pengajaran dan penilaian memberi impak yang besar kepada pembangunan modal insan. Pembelajaran banyak bergantung kepada dinamik interaksi antara dua elemen utama tersebut. Namun, terdapat kekurangan dalam percambahan penerapan nilai dan kekuatan penghayatan akhlak setelah pelajar mengambil kursus CTU 151. Kajian Rubiah et al. (2017) menunjukkan perlunya isi kandungan kursus disusun dan dirancang dengan begitu teliti supaya pelajar dapat didedahkan kepada ilmu tentang ketamadunan dan sumbangannya kepada peradaban dunia. Kajian seumpama ini juga turut dilakukan Faridah et al. (2018) mengenai pelaksanan dan persepsi pelajar terhadap strategi pembelajaran dan kemahiran insaniah dalam kursus Tamadun Islam dan Tamadun Asia (TITAS) di Universiti Malaya. Namun, beliau mendapati persepsi pelajar terhadap strategi pembelajaran dan kaedah penilaian adalah signifikan dan memberi kesan positif kepada pencapaian yang diperoleh dalam penilaian kerja kursus dan pencapaian kemahiran insaniah. Beliau juga mencadangkan penambahbaikan perlu terus dilakukan kepada kursus bagi memastikan kelangsungan nilai-nilai ketamadunan dalam pembinaan tamadun Malaysia.

Pengamalan nilai-nilai murni dalam kursus Tamadun Islam dan Tamadun Asia (TITAS) ke arah pembentukan sahsiah pelajar turut dijalankan. Kajian Mohd Azrul et al. (2017) mendapati tahap kefahaman dan pengamalan nilai murni dalam kusus TITAS berada pada tahap tinggi. Dapatan ini dibuktikan dengan skor min yang diperoleh bagi setiap konstruk berada di tahap yang tinggi. Ini menunjukkan bahawa elemen-elemen nilai murni seperti dalam konstruk kepercayaan agama, akhlak serta moral berada di tahap yang sangat tinggi dan boleh diterapkan dalam kalangan pelajar. Dapatan kajian ini sejajar dengan pandangan (Ahmad Firdaus 2017) pelajar perlu digalakkan mencontohi dan mengamalkan nilai-nilai yang baik sebagai satu penghayatan ketrampilan diri dan kualiti warganegara yang baik serta prihatin terhadap soal-soal kehidupan dan pembinaan diri. Menurut kajian (Suraya Ishak et al. 2014) berkaitan pandangan pelajar tentang penggunaan kes dalam pembelajaran subjek etika. Hasil kajian menunjukkan bahawa penggunaan kes semasa membolehkan pelajar memahami teori dan aplikasi teori etika dengan lebih baik. Selain itu, penggunaan kes semasa membolehkan pelajar mendapat pengetahuan tentang isu etika yang berpotensi mereka hadapi setelah memasuki alam pekerjaan dan persekitaran industri yang sebenar. 
Jadual 1.3. Ringkasan Literatur Nilai Etika dan Moral Pelajar di Institusi Pengajian Tinggi di Malaysia

\begin{tabular}{|c|c|c|c|c|c|}
\hline Kajian & Sampel Kajian & $\begin{array}{c}\text { Reka bentuk } \\
\text { Kajian }\end{array}$ & $\begin{array}{c}\text { Instrumen } \\
\text { Kajian }\end{array}$ & Dapatan Kajian & Tema \\
\hline $\begin{array}{l}\text { Abdul Muqsith } \\
\text { (2017) }\end{array}$ & $\begin{array}{l}410 \text { pelajar } \\
\text { kemahiran } \\
\text { kejuruteraan }\end{array}$ & Kuantitatif & $\begin{array}{l}\text { Analisis } \\
\text { dokumen, } \\
\text { soal selidik } \\
\text { pelajar. }\end{array}$ & $\begin{array}{l}\text { Statistik menunjukkan } 72.9 \% \\
\text { masalah etika dan akhlak pelajar } \\
\text { ini berlaku dalam kalangan } \\
\text { pelajar kemahiran kejuruteran di } \\
\text { sepanjang pengajian mereka } \\
\text { walaupun sekali. } \\
\text { menggambarkan } \\
\text { permasalahan etika dan akhlak } \\
\text { berlaku di institusi pendidikan } \\
\text { masa kini. }\end{array}$ & $\begin{array}{c}\text { Etika dan } \\
\text { akhlak pelajar }\end{array}$ \\
\hline $\begin{array}{l}\text { Shahrulanuar } \\
\text { Mohamed } \\
(2011)\end{array}$ & 371 pelajar UTeM & Kuantitatif & $\begin{array}{c}\text { Analisis } \\
\text { dokumen } \\
\text { dan soal } \\
\text { selidik } \\
\text { pelajar }\end{array}$ & $\begin{array}{l}\text { Hasil kajian } \begin{array}{r}\text { mendapati } \\
\text { keberkesanan pembangunan }\end{array} \\
\text { etika dan moral menerusi kursus } \\
\text { yang ditawarkan berdasarkan tiga } \\
\text { aspek iaitu pengetahuan, amalan } \\
\text { dan sikap. Halangan kepada } \\
\text { keberkesanan } \\
\text { diketengahkan juga } \\
\text { perspektif pensyarah dan pelajar }\end{array}$ & $\begin{array}{l}\text { Pengajaran } \\
\text { dan } \\
\text { pembelajaran } \\
\text { etika dan } \\
\text { moral }\end{array}$ \\
\hline $\begin{array}{c}\text { Suraiya Ishak } \\
\text { (2014) }\end{array}$ & $\begin{array}{l}30 \text { orang pelajar } \\
\text { kursus etika, } \\
\text { perundangan dan } \\
\text { pembangunan }\end{array}$ & kuantitatif & $\begin{array}{l}\text { Borang soal } \\
\text { selidik }\end{array}$ & $\begin{array}{l}\text { Hasil kajian menunjukkan } \\
\text { penggunaan kes telah } \\
\text { membolehkan pelajar memahami } \\
\text { teori dan aplikasi teori etika } \\
\text { dengan lebih baik. Pelajar lebih } \\
\text { menguasai teori etika dengan } \\
\text { pengajaran menggunakan kajian } \\
\text { kes. }\end{array}$ & $\begin{array}{c}\text { Pembelajaran } \\
\text { subjek etika }\end{array}$ \\
\hline $\begin{array}{l}\text { Faridah Che } \\
\text { Husain et.al } \\
\quad(2018)\end{array}$ & $\begin{array}{l}\text { Analisis Modul } \\
\text { TITAS }\end{array}$ & Kualitatif & $\begin{array}{l}\text { Analisis } \\
\text { dokumen }\end{array}$ & $\begin{array}{l}\text { Wujud beberapa elemen yang } \\
\text { mampu menyumbang ke arah } \\
\text { pembentukan akhlak dan moral } \\
\text { dalam modul pengajian kursus } \\
\text { TITAS yang ditawarkan di } \\
\text { Universiti Malaya. }\end{array}$ & $\begin{array}{l}\text { Pembentukan } \\
\text { akhlak dan } \\
\text { moral pelajar }\end{array}$ \\
\hline $\begin{array}{l}\text { Ainul Widad } \\
\text { Muhd Fuzi et. } \\
\text { al (2018) }\end{array}$ & $\begin{array}{c}\text { Analisis kitab al- } \\
\text { Ghazali }\end{array}$ & Kualitatif & $\begin{array}{l}\text { Analisis } \\
\text { Dokumen }\end{array}$ & $\begin{array}{l}\text { Penerapan nilai dalam } \\
\text { pengajaran menggunakan teori } \\
\text { al-Ghazali perlu diterapkan } \\
\text { seperti kaedah tauladan, } \\
\text { pembiasaan, nasihat, ganjaran } \\
\text { dan hukuman penerapan nilai. } \\
\text { Guru perlu menguasai dengan } \\
\text { lebih luas kaedah dan teknik yang } \\
\text { berkesan agar memberi impak } \\
\text { yang sangat besar dalam } \\
\text { pembentukan akhlak pelajar }\end{array}$ & $\begin{array}{l}\text { Penerapan } \\
\text { Nilai }\end{array}$ \\
\hline $\begin{array}{l}\text { Mohamad } \\
\text { Khairi } \mathrm{Hj} \\
\text { Othman } \\
(2016)\end{array}$ & $\begin{array}{c}448 \text { pelajar } \\
\text { Tingkatan } 4 \\
\text { Sekolah Harian }\end{array}$ & Kuantitatif & $\begin{array}{l}\text { Soal selidik } \\
\text { pelajar }\end{array}$ & $\begin{array}{l}\text { Teknik penerapan nilai murni } \\
\text { yang paling tinggi dan kerap } \\
\text { diamalkan adalah teknik } \\
\text { model/contoh yang baik. Teknik } \\
\text { syarahan/kuliah merupakan } \\
\text { teknik kedua tertinggi untuk guru } \\
\text { menerapkan nilai-nilai murni } \\
\text { kepada pelajar. }\end{array}$ & $\begin{array}{l}\text { Penerapan } \\
\text { nilai }\end{array}$ \\
\hline $\begin{array}{l}\text { Rashidi Abbas } \\
\text { et.al (2014) }\end{array}$ & $\begin{array}{l}480 \text { pelajar } \\
\text { daripada MTUN } \\
\text { Universiti }\end{array}$ & Kuantitatif & $\begin{array}{l}\text { Soal selidik } \\
\text { Pelajar }\end{array}$ & $\begin{array}{l}\text { Data menunjukkan kemampuan } \\
\text { yang tinggi dari segi penguasaan } \\
\text { kemahiran insaniah (etika } \\
\text { profesional dan kemahiran }\end{array}$ & $\begin{array}{l}\text { Penerapan } \\
\text { nilai Amanah } \\
\text { dan etika }\end{array}$ \\
\hline
\end{tabular}




\begin{tabular}{|c|c|c|c|c|}
\hline $\begin{array}{l}\text { Mohamad } \\
\text { Khairi Othman } \\
\text { et. al. (2019) }\end{array}$ & Guru-guru KPM & kualitatif & $\begin{array}{c}\text { Analisis } \\
\text { dokumen } / \mathrm{m} \\
\text { odul }\end{array}$ & $\begin{array}{l}\text { Dapatan kajian membuktikan } \\
\text { bahawa modul etika kerja KPM } \\
\text { ini mempunyai kesahan dan } \\
\text { kebolehpercayaan yang tinggi. } \\
\text { Kajian ini mendapati, semua } \\
\text { aktiviti yang terkandung dalam } \\
\text { modul ini adalah sesuai dan boleh } \\
\text { digunakan sebagai alat, bahan, } \\
\text { sumber dan panduan yang boleh } \\
\text { memberi bimbingan, kesedaran, } \\
\text { keinsafan, semangat dan motivasi } \\
\text { kepada semua guru sekolah di }\end{array}$ \\
\hline
\end{tabular}

\section{PERBINCANGAN}

Berdasarkan sorotan penulisan di atas, pengkaji ingin menegaskan bahawa konsep nilai etika dan moral ini amat penting di dalam pembinaan sahsiah pelajar. Penerapan nilai etika dan moral ini bukan sahaja berlangsung di dalam proses pengajaran dan pembelajaran semata-mata tetapi perlu ditekankan diluar sesi pengajaran. Namun, kursus-kursus yang ditawarkan berkaitan dengan akhlak di universiti juga perlu diberi keutamaan. Ini kerana konsep akhlak itu sendiri menggabungkan nilai dalaman dan luaran dalam pembangunan sahsiah pelajar berbanding etika dan moral yang hanya melihat dari sudut luaran dan tingkah laku. Dalam Pelan Pembangunan Pendidikan Malaysia 2013-2025 aspek Falsafah Pendidikan Kebangsaan terus didokong dengan memberi pendidikan yang seimbang melalui elemen nilai, etika dan kerohanian yang harus dipupuk dalam pengajaran dan pembelajaran (Kementerian Pendidikan Malaysia 2013).

Usaha-usaha sewajarnya harus difikirkan bagi mencari jalan agar kefahaman dari segi dimensi etika dan moral perlu seiring dengan pembangunan akhlak pelajar. Isu masalah sosial dalam kalangan pelajar tidak boleh dipandang mudah kerana matlamat sebenar proses pendidikan ialah melahirkan pelajar yang berakhlak mulia. Menurut Rohana (2010), proses pembangunan manusia bermula dengan kesedaran diri iaitu bermula dengan pembangunan spiritual. Setelah mempunyai pembangunan spiritual yang tinggi dalam diri, manusia akan terdorong untuk menguasai setiap perkara dalam kehidupan mereka. Oleh itu, dengan menekankan proses pendidikan yang berteraskan pembangunan spiritual akan mampu menjadi landasan yang kukuh bagi melahirkan pelajar yang seimbang, menyeluruh dan bersepadu selari dengan matlamat pendidikan kebangsaan.

Pengkaji mencadangkan tindakan susulan IPT untuk menambahbaik terhadap kursuskursus elektif yang ditawarkan perlu ada satu kursus yang memfokuskan kepada akhlak pelajar. Ini kerana kursus tersebut juga berpotensi untuk membangunkan nilai-nilai akhlak dalam kalangan pelajar walaupun kursus baharu yang ditawarkan telah ada iaitu Falsafah Etika dan Peradaban. Satu garis panduan untuk mengukur dan menilai etika, akhlak dan moral pelajar perlu dibangunkan di semua IPT untuk memudahkan para pensyarah dan tenaga pengajar melakukan penilaian dan pengukuran setiap pelajar secara holistik bagi memperolehi sahsiah pelajar yang tinggi bukan sahaja semasa di dalam pengajian malah di alam pekerjaan kelak. 


\section{KESIMPULAN}

Kesimpulannya, dapatlah dirumuskan bahawa nilai etika dan moral yang sedia ada seharusnya dipupuk dan diperkukuhkan dalam kalangan pelajar untuk mencapai pembangunan yang beerti bagi mencerminkan tingginya peradaban seseorang pelajar. Kefahaman yang jelas berkaitan nilai etika dan moral sewajarnya diambil berat oleh semua pelajar. Ini kerana melalui nilai etika dan moral dapat memberi impak yang besar kepada pelajar dalam kawal selia diri dalam urusan kehidupan. Hal ini juga perlu ditegaskan bahawa penerapan nilai etika dan moral perlu dilaksanakan untuk memberi kesedaran kepada pembangunan masyarakat sivil yang menekankan kepada peningkatan moral dan integriti dalam sistem masyarakat. Melalui perbincangan yang dikemukakan wujudnya kelompangan yang wajib dijalankan pengkaji berkaitan instrumen nilai etika dan moral terhadap pelajar di IPT. Dalam konteks ini, kemahiran tentang nilai dan etika wajar diajar melalui kaedah secara formal atau secara informal dan ianya merupakan salah satu kaedah yang berkesan bagi memberi pendedahan kepada pelajar atau pekerja mengenai kepentingan nilai, etika, akhlak dan moral serta isu-isu berkaitan.

\section{PENGHARGAAN}

Penulis ingin berterima kasih kepada para penilai serta editor dalam proses menilai artikel ini. Penulis ingin merakamkan penghargaan kepada penyelia serta para pakar yang telah memberikan tunjuk ajar dan kerjasama dalam penghasilan kertas kajian ini. Penulis juga ingin berterima kasih kepada penaja Hadiah Latihan Persekutuan (HLP) Kementerian Pendidikan Malaysia (KPM.BT.700-30/18/134) dalam memberikan segala bentuk bantuan sepanjang pengajian. Dapatan ini dapat membantu serta mewajarkan pengkaji dalam mengisi kelompangan kajian bagi membangunkan satu instrumen penilaian berkaitan etika dan moral dalam kalangan pelajar di Rangkaian Universiti Teknikal Malaysia (MTUN).

\section{RUJUKAN}

A.Aziz Deraman. 2015. Minda Dunia Melayu. Dewan Bahasa dan Pustaka. Kuala Lumpur. Abdul Muqsith Ahmad, Zaharah Hussin, Farazila Yusof \& Mohd Ridhuan Jamil. 2017. Masalah etika dan akhlak pelajar kemahiran kejuruteraan: Analisis keperluan. Jurnal Kurikulum \& Pengajaran Asia Pasifik. April 2017, Bil. 5, Isu 2.

Adibah Abdul Latif. 2013. Pembangunan instrumen penilaian akhlak pelajar di Institusi Pengajian Tinggi Awam. Tesis Doktor Falsafah. Fakulti Pendidikan, Universiti Teknologi Malaysia.

Ahmad Bashir Aziz. 2004. Nilai dan etika pengurusan: Analisa dari perspektif agama-agama di Malaysia. Seminar Nilai dalam Komuniti (SIVIC). Anjuran Jabatan Pengajian Umum Ahmad Firdaus Mohd Noor. 2017. Pensyarah cemerlang Pendidikan Islam di Politeknik: Satu kajian kes. Tesis Doktor Falsafah. Universiti Teknologi Malaysia. Skudai.

Al Hasan Al Aidaros, Faridahwati Mohd Shamsudin \& Kamil Md Idris. 2013. Ethics and Ethical Theories from an Islamic Perspective. International Journal of Islamic Thought (IJIT), vol. 4, 1-13.

Amini Amir Abdullah. 2007. Nilai, kerja kuat, kenegaraan dan patriotism. Dlm. Mohamad Hj Alias, Mohd Safar Hashim, Sapora Sipon, Arshad Hamzah \& Shariffah Bahyah Syed Ahmad (pnyt.). Koleksi Rencana Merdeka. Hlm. 197-199. Nilai: Universiti Sains Islam Malaysia 
Bertens, K. 2003. Etika dan Moral untuk Pengajian Tinggi. Kuala Lumpur: Penerbit Universiti Malaya.

Crown, D.F \& Spiller, M.S. 1998. Learning from the literature on collegiate cheating: A review of empirical research . Journal of Business Ethics 24: 179-183.

Enida Daud, Low Hock Heng \& Ahmad Muhyuddin Hassan. 2019. Etika kerja Islam sebagai pembolehubah penyederhanaan terhadap niat untuk melakukan rasuah di kalangan penjawat awam pihak berkuasa tempatan negeri Johor. Jurnal Islam dan Masyarakat Kontemporari, 20(1) 2019: 155-177.

Faridah Che Husain, Faezah Kassim, Noor Ain Mat Noor, Muhammad Shamshinor Abdul Azzis \& Mohd Syariefudin Abdullah. 2018. Pelaksanaan dan persepsi pelajar terhadap strategi pembelajaran dan kemahiran insaniah dalam kursus Tamadun Islam dan Tamadun Asia (TITAS) di Universiti Malaya. Sains Insani 2018, Volume 03 No 02: 7482.

Hamzah Yaakob. 1985. Etika Islam. Bandung cv Deponegoro. 13.

Hasnah Hussin. 2009. Artikel kenegaraan dan hubungan etnik. Cetakan pertama 2009. Penerbit Universiti Malaysia Pahang. Kuatan Pahang Darul Makmur.

Khairul 'Azmi Mohamad \& Nooraini Othman. 2009. Nilai yang mendasari integriti dan amalan masyarakat hadhari. Dlm. Khairul Azmi Mohamad, Shaikh Mohd Saifuddeen Shaikh Mohd Salleh \& Norhanizah Ismail (pnyt.). Ke Arah Umat Hadhari, hlm.122-130 Yayasan Ilmuan, Taman setiawangsa Kuala Lumpur.

Latifah Abdul Majid, Wan Nasyrudin Wan Abdullah \& Nurul Hidayah Ahmad Zakhi. 2012. Penerapan nilai murni dan pembentukan jati diri kanak-kanak prasekolah melalui penggunaan multimedia. Jurnal Hadhari Special Edition (2012) 51-65. Universiti Kebangsaan Malaysia.

Lawson, R.A. 2004. Is Classroom Cheating Related to Business Students Propensityto Cheat in The 'Real World'? Journal of Business Ethics, 49(2): 189-199.

Manshuruddin Jabaidin. 2003. Moral Kunci Pembangunan dalam Islam. Johor Bharu. Perniagaan Jahabersa.

Megat Ayop Megat Arifin \& Abd. Halim Ahmad. 2016. Kepentingan budaya integriti etika kerja dalam organisasi di Malaysia: Suatu tinjauan umum. Malaysian Journal of Society and Space, 12 Issue 9 (138-149).

Mohamad Khairi Othman, Alias Puteh, Mohd Zailani Mohd Yusof \& Fauziah Abdul Rahim. 2019. Keperluan penggunaan modul etika kerja guru dalam meningkatkan penghayatan nilai pelajar. Islāmiyyāt 4(1) 2019: 49-57.

Mohamad Khairi Othman, Asmawati Suhid \& Samsilah Roslan. 2015. Penghayatan nilai murni dalam kalangan pelajar sekolah menengah masa kini. Jurnal Pembangunan Sosial Jilid 18 (Jun) 2015: 1-20.

Mohamad Sabri Haron, Aminuddin Basir, Nasruddin Yunos, Mohamad Taha \& Nik Yusri Musa. 2014. Tamadun Islam. Dlm. Nasruddin Yunos, Aminudin Basir, Jamsari Alias \& Wan Zulkifli Wan Hassan (pnyt.). Tamadun Islam dan Tamadun Asia, hlm. 22-57. Bangi: Pusat Citra Universiti, Universiti Kebangsaan Malaysia.

Mohd Azrul Jaafar, Azrina Tahir \& Ahmad Firdaus Mohd Noor. 2017. Pengamalan nilai-nilai murni dalam kursus Tamadun Islam dan Tamadun Asia (TITAS) ke arah pembentukan sahsiah pelajar Politeknik Malaysia. Malaysian Online Journal of Education. Vol. 1, No. 1 (2017), 29-35.

Mohd Ismail Mustari, Ahmad Kailani Mohamed, Kamarul Azmi Jasmi \& Robiah Ya'akob. 2004. Pembentukan nilai dan kecemerlangan bagi melahirkan generasi muda yang mapan dalam menghadapi era pasca modenisme. Seminar Antarabangsa Nilai Dalam Komuniti Pasca Modenisme 2004. 
Mohd Nazmi Awang Besar, Maimun Aqsha Lubis \& Hamdan Arman Al-Banjari. 2011. Kesan tamadun Islam terhadap perkembangan masyarakat dunia. Dlm. Maimun Aqsha Lubis (pnyt.). Peradaban Islam \& Tamadun Dunia, hlm. 193-208. Bangi. Fakulti Pendidikan, Universiti Kebangsaan Malaysia.

Mohd Ridhuan Mohd Jamil. 2007. Rekabentuk Kerangka Piawaian Transnasional Bagi Program Tenaga Pengajar TVET. Tesis Sarjana. Universiti Tun Hussein Onn Malaysia.

Muhammad Iqbal Samadi \& Noorzaid Muhammad. 2018. Etika sosial dalam manhaj pembentukan dan ketrampilan sahsiah pelajar yang unggul berteraskan surah Al-Hujurat. Proceedings of the 5th International Conference On Research in Islamic Education and Arabic Language 2018 (ICRIALE 2018), hlm. 255-263.

Mustafa Haji Daud. 2002. Tamadun Islam. Utusan Publications \& Distributors Sdn Bhd. Kuala Lumpur.

Nonis S.\& Swift C.O. 2001. An examination of the relationship between academic dishonesty and workplace dishonesty: A multicampus investigation. Journal of Education for Business 77: 69-77.

Norazri Mohd Zaidin. 2015. Penerapan nilai-nilai murni dalam proses pengajaran dan pembelajaran ke arah pembentukan sahsiah pelajar di Kolej Kemahiran Tinggi Mara. Tesis Sarjana Pendidikan Teknik dan Vokasional. Universiti Tun Hussein Onn Malaysia.

Noresah Baharom (eds). 2005. Kamus Dewan, Edisi ke-4, Cet.1. Kuala Lumpur: Dewan Bahasa dan Pustaka.

Poerwadarminto. 2006. Kamus Umum Bahasa Indonesia. Edisi III. Cet.III. Jakarta: Balai Pustaka

Rashidi Abbas, Fakhrul Adabi Abdul Kadir \& Ilhamie Abdul Ghani Azmi. 2014. Kemahiran Generik: Hubungan nilai amanah dengan etika moral profesional dalam kalangan pelajar Universiti Teknikal Malaysia. The Online Journal of Islamic Education. July 2014, Vol. 2 Issue 2.

Rubiah Abu Bakar, Che Zuina Ismail, Azarudin Awang \& Noor Hasyimah Sulaiman. 2017. Analisis kerelevanan kurikulum kursus pemikiran dan Tamadun Islam (CTU151) terhadap pelajar di UiTM. Proceedings of $2^{\text {nd }}$ International Islamic Heritage Conference (ISHEC 2017).

Saedah Siraj, Farazila Yusof, Mohd Ridhuan Mohd Jamil, Zaharah Hussin, Nurulrabihah Mat Noh, Ahmad Arifin Sapar \& Azmi Omar. 2016. Elemen nilai berasaskan hubungan: Suatu kajian terhadap keperluan pelajar kejuruteraan yang mengikuti pengajian berasaskan Work-Based Learning(WBL) Politeknik Malaysia. Journal of Holistic Student Development. Vol.1, No. 1 (2016).

Sapie Sabilan, Suhana Mohamed Lip, Mohammad Fuad Ishak, Shazarina Zdainal Abidin \& Suziana Hanini Sulaiman. 2016. Konsep penerapan dan penghayatan nilai-nilai murni berasaskan falsafah Pendidikan Kebangsaan (FPK). International Conference on Moslem Society 2016, Kolej Universiti Islam Antarabangsa Selangor (KUIS).

Shahrulanuar Mohamed, Ab. Aziz Mohd Zin \& Fakhrul Adabi Abdul Kadir. 2011. Pembangunan etika dan moral dalam kursus-kursus yang ditawarkan di Universiti Teknikal Malaysia Melaka (UTeM). Journal of Human Capital Development. Vol.4 No.1 January-June 2011.

Sharifah Hayaati Ismail al-Qudsy. 2010. Etika Penjawat Awam dari Perspektif Islam. Kuala Lumpur: Dewan Bahasa dan Pustaka.

Shukri Ahmad \& Musa Yusof Owoyemi. 2012. The Concept of Islamic Work Ethic: An Analysis of Some Salient Points in the Prophetic Tradition. International Journal of Business and Social Science Vol. 3 No. 20. Special Issue -October 2012.

Shukri Ahmad. 2002. Konsep Tamadun dan Ciri-Ciri ke arah pembangunan. Dlm. Wan Ab. Rahman Khudzri Wan Abdullah, Munif Zarirruddin Fikri Nordin \& Solahuddin Ismail 
(pnyt.). Tamadun Islam Suatu Sorotan, hlm. 1-17. PTS Publication \& Distributor Sdn. Bhd. Terbitan pertama 2002. Pahang Darul Makmur.

Sinar Harian. 2019. Biadap Graduan protes di pesta konvo. 15 Oktober

Siti Arni Basir, Nurul Syafiyah Mohd Noor, Mohamad Zaidi Abd Rahman \& Monika @ Munirah Abd Razak. 2016. Peranan pemimpin dalam pelaksanaan etika kerja Islam: Kajian kes di Johor Corporation (Jcorp). Jurnal Usuluddin 44 (Julai-Disember2016): 4583.

Sufean Hussin. 1995. Pengajaran nilai dalam kurikulum. Penerbit Fajar Bakti Sdn Bhd. Edisi kedua.

Suraya Ishak, Raflis, A., Omar, C., Ariffin, K. \& Hussain, M. Y. 2014. Pandangan pelajar tentang penggunaan kes dalam pembelajaran subjek etika. Geografia: Malaysian Journal of Society \& Space 10(1): 60-69.

Taufik Abdul Latif, Mohd Syuja Saedin, Norazilah Buhari \& Ira Meilita Ibrahim. 2018. Amalan "berbudi bahasa": Satu kajian nilai peradaban masyarakat Malaysia. Jurnal Sains Insani 2018, Volume 03 No 2: 68-73.

The Star Online. 2019. UM lodges report overgraduate's protest at convocation ceremony. 15 Oktober.

Thompson, D.(ed.).1995. The Concise Oxford Dictionary. Clarendon Press: Oxford.

Zaharah Hassan, Abu Daud Silong \& Nazri Muslim. 2009. Kepimpinan beretika dan kecemerlangan organisasi dalam perkhidmatan awam. MALIM, Bil. 10.

Zaharah Hussin, Saedah Siraj, Zai Hazreen Ab Malik, Mohd Ridhuan Mohd Jamil, Ahmad Arifin Sapar \& Nurul Rabihah Mat Noh. 2015. Pembangunan akhlak dan moral ke arah masyarakat Lestari. Jurnal Al-Hikmah, 7(2) 2015: 72-87.

Zaid Ahmad, Ruslan Zainuddin, Sarjit Singh Gill, Ahmad Tarmizi Talib, Ho Hui Ling, Lee Yok Fee, Najeemah Mohd Yusof \& Nazri Muslim. 2013. Hubungan Etnik di Malaysia. Oxford Fajar Sdn. Bhd. Cetakan pertama. Shah Alam Selangor Darul Ehsan.

Zainal Yang. 2003. Nilai, etika dan budaya kerja dalam pentadbiran sektor awam di Malaysia dari perspektif Islam (Satu Imbasan kembali tinjauan karya). Jurnal Pengurusan Awam, Jilid 2 Bilangan 1 Januari 2003.

Zurina Mahadi \& Hukil Sino. 2007. Hubungan nilai masyarakat dan pembangunan: satu analisa. Jurnal Pengajian Umum, Bil 8: 77-94.

\section{RUSLAN BIN HASSAN}

Pusat Kajian Bahasa Arab dan Tamadun Islam

Fakulti Pengajian Islam

Universiti Kebangsaan Malaysia

\section{FARID MAT ZAIN}

Pusat Kajian Bahasa Arab dan Tamadun Islam

Fakulti Pengajian Islam

Universiti Kebangsaan Malaysia

E-mel: farid@ukm.edu.my

\section{KASEH ABU BAKAR}

Pusat Kajian Bahasa Arab dan Tamadun Islam

Fakulti Pengajian Islam

Universiti Kebangsaan Malaysia

E-mel:kaseh@ukm.edu.my 


\section{AZMUL FAHIMI KAMARUZZAMAN}

Pusat Kajian Bahasa Arab dan Tamadun Islam

Fakulti Pengajian Islam

Universiti Kebangsaan Malaysia

E-mel: azmul@ukm.edu.my

*Pengarang untuk surat menyurat: ruslanhassan37@gmail.com 